University of Nebraska - Lincoln

DigitalCommons@University of Nebraska - Lincoln

Publications from USDA-ARS / UNL Faculty

U.S. Department of Agriculture: Agricultural

Research Service, Lincoln, Nebraska

3-16-2016

\title{
Low-Intensity, Stocker-Based Channel Catfish Culture
}

Bartholomew W. Green

bart.green@usda.gov

Carole R. Engle

University of Arkansas at Pine Bluff

Rebecca Lochmann

University of Arkansas at Pine Bluff

Harold Phillips

University of Arkansas at Pine Bluff

Follow this and additional works at: https://digitalcommons.unl.edu/usdaarsfacpub

Part of the Agriculture Commons, and the Aquaculture and Fisheries Commons

Green, Bartholomew W.; Engle, Carole R.; Lochmann, Rebecca; and Phillips, Harold, "Low-Intensity, Stocker-Based Channel Catfish Culture" (2016). Publications from USDA-ARS / UNL Faculty. 2398.

https://digitalcommons.unl.edu/usdaarsfacpub/2398

This Article is brought to you for free and open access by the U.S. Department of Agriculture: Agricultural Research Service, Lincoln, Nebraska at DigitalCommons@University of Nebraska - Lincoln. It has been accepted for inclusion in Publications from USDA-ARS / UNL Faculty by an authorized administrator of DigitalCommons@University of Nebraska - Lincoln. 


\title{
ARTICLE
}

\section{Low-Intensity, Stocker-Based Channel Catfish Culture}

\author{
Bartholomew W. Green*1 \\ U.S. Department of Agriculture-Agricultural Research Service, Aquaculture Systems Research Unit, \\ University of Arkansas at Pine Bluff, 1200 North University Drive, Mail Slot 4912, Pine Bluff, \\ Arkansas 71601, USA
}

Carole R. Engle, ${ }^{2}$ Rebecca Lochmann, and Harold Phillips

Aquaculture/Fisheries Center, University of Arkansas at Pine Bluff, 1200 North University Drive, Mail Slot 4912, Pine Bluff, Arkansas 71601, USA

\begin{abstract}
Low-intensity production of Channel Catfish Ictalurus punctatus is characterized by low stocking rates, low installed aeration capacity, and no automated dissolved oxygen monitoring. Two studies conducted in nine 0.25-acre ponds quantified production characteristics of stocker Channel Catfish stocked for low-intensity food-fish production in single- or multiple-batch culture. In the multiple-batch study, 0.5-lb stockers (carryover fish) were stocked at 4,500 fish/acre and 0.044-lb fingerlings at 6,000 fish/acre. Stockers were grown to mean individual weights of 1.25, 1.75 , or $2.25 \mathrm{lb}$. In the single-batch study, 0.5 -lb stockers were stocked at 3,500, 4,500, and 5,500 fish/acre. All fish were fed a feed containing $32 \%$ protein daily to apparent satiation. Ponds were harvested in October and fish were weighed. Growth of carryover fish and understock (fingerlings) in multiple-batch culture was linear and growth-curve slopes did not differ significantly. Carryover fish size-class distributions differed significantly among target weights and progressively shifted towards larger size-classes as target weight increased. Stocking rate affected Channel Catfish growth and yield significantly in single-batch culture. Fish stocked at 3,500 fish/acre grew faster than fish at the higher stocking rates. Mean final weight decreased linearly and gross and net yields increased linearly with increased stocking rate. Size-class distributions differed significantly among stocking rates, and the 3,500-fish/acre size-class distribution was shifted towards larger fish compared with those at the other two stocking rates. By early to mid-July, ponds stocked in the spring with 0.5 -lb stockers contained biomasses of market-size fish suitable for partial harvest, and at least $22 \%$ of the carryover fish exceeded the lower size limit for the processing plant. If fish larger than $1.5 \mathrm{lb}$ are desired, the data indicated partial harvest should be delayed until August. None of the fish harvested exceeded the processors' preferred size ranges (1.25-4.00 lb/fish). In summary, larger Channel Catfish can be produced successfully using low-intensity, single- or multiple-batch culture.
\end{abstract}

Catfish farmers use a variety of pond management strategies to produce food-size catfish. These management strategies have evolved over time towards increased intensification. Catfish farmers in the major catfish-producing states (Alabama, Arkansas, Louisiana, and Mississippi) are surveyed periodically about their management, production, and health practices by the U.S. Department of Agriculture (USDA) National Animal Health Monitoring System (NAHMS), with the latest survey being conducted in 2009 (USDA NAHMS 2010). The effect on catfish yield, production costs, and economic risk of production practices documented in the USDA NAHMS (2010) report was evaluated recently (Johnson et al. 2014). Those

*Corresponding author: bart.green@ars.usda.gov

${ }^{1}$ Present address: U.S. Department of Agriculture-Agricultural Research Service, Harry K. Dupree Stuttgart National Aquaculture Research Center, Post Office Box 1050, Stuttgart, Arkansas 72160, USA.

${ }^{2}$ Present address: Engle-Stone Aquatic $\$$ LLC, 1225 Cottonwood Road, Strasberg, Virginia 22657, USA.

Received September 28, 2015; accepted November 13, 2015 
authors identified three management strategies that had the lowest cost per pound of fish produced. Two were high-intensity production strategies using Channel Catfish Ictalurus punctatus or hybrid catfish (Channel Catfish $\times$ Blue Catfish I. furcatus). The third was a low-intensity, low-technology, Channel Catfish production strategy characterized by low stocking rates (ca. $4,800 \mathrm{fish} / \mathrm{acre})$, a low amount of installed aeration ( $2.0 \mathrm{hp} / \mathrm{acre})$, and no automated dissolved oxygen (DO) monitoring.

Catfish processors continue to seek larger fish for processing and the preferred size range generally ranges from 1.25 to $4.00 \mathrm{lb} /$ fish (Wiese et al. 2006). But the preferred size range varies from plant to plant and over time in response to market demands. Processors likely prefer a tighter size range (from 1.5 to $2.5 \mathrm{lb} / \mathrm{fish}$ ) with minimal numbers of fish at and above 3 lb. Stocking production ponds with stocker catfish is one strategy used by farmers to produce fish larger than $1.25 \mathrm{lb} / \mathrm{fish}$. Stocker-size catfish range from 62.5 to $751.8 \mathrm{lb} / 1,000$ fish as defined by the USDA, based upon National Agricultural Statistics Services data collection protocol (USDA NAHMS 2010). Traditionally, catfish that weigh from 200 to $750 \mathrm{lb} / 1,000$ fish are defined as stockers (Lee 1981). Up to $97.4 \%$ of the Channel Catfish population harvested from low-intensity ponds stocked with 0.5 -lb stockers in single-batch culture weighed from 1.25 to $4.00 \mathrm{lb} / \mathrm{fish}$, and nearly $60 \%$ weighed $1.50-2.50 \mathrm{lb} / \mathrm{fish}$ after $210 \mathrm{~d}$ of grow out (Green and Engle 2004). In a 200-d lowintensity study designed to grow large $(>3.0 \mathrm{lb}$ ) food fish, more than $80 \%$ of the large stockers ( $800 \mathrm{lb} / 1,000 \mathrm{fish}$ ) in single-batch culture reached the minimum target weight across all stocking rates (Engle and Kumar 2011). At stocking rates less than 3,000 fish/acre, $93 \%$ of the fish reached the minimum target weight. Understocked fish (fingerlings) do not appear to affect growth of large (0.8-1.0 lb/fish) carryover fish in multiple-batch production (Southworth et al. 2006a, 2009; Nanninga and Engle 2010), but how smaller stockers will perform in a low-intensity, multiple-batch system is unknown.

Bastola and Engle (2012) reviewed production relationships in pond culture of Channel Catfish. Growth and yield of Channel Catfish are affected by stocking rate. Growth generally decreases linearly in response to increased stocking rate, and while yield from ponds increases with stocking rate, the increase is not directly proportional (e.g., Tucker et al. 1993; Li et al. 2003; Robinson and Li 2008). Stocking-rate studies on Channel Catfish have focused on density-dependent growth of fingerlings stocked into grow-out ponds. No information was found on the effects of stocking rate on pond grow out of stockers.

In response to increasing market demand for larger catfish fillets, catfish processors increased the minimum marketable size and lowered the tolerance level for fish outside of the preferred size range. Given the dearth of systematic research data on the production of larger Channel Catfish, we conducted three studies in which the objectives were to quantify production characteristics, including temporal changes in population size distribution and response to stocking rate, when 0.5-lb stocker Channel Catfish were stocked at low intensity for food fish production either in single- or multiple-batch culture. Results of the first study on grow out of stockers to market-size fish in single-batch culture are published (Green and Engle 2004). In this paper, we report results of the second and third studies (referred to herein as studies 1 and 2, respectively), along with unpublished dress-out data from the first study.

\section{METHODS}

Studies 1 and 2 were conducted in consecutive years at the Aquaculture Research Station, University of Arkansas at Pine Bluff (UAPB). Nine 0.25-acre earthen ponds filled with well water (total alkalinity, $52 \mathrm{mg} / \mathrm{L}$ as $\mathrm{CaCO}_{3}$ ) were used for each study. Water was added to ponds only to replace seepage and evaporation losses. Stock salt ( $\mathrm{NaCl}, 600 \mathrm{lb} / \mathrm{acre})$ was added to each pond to increase chloride concentration as prophylaxis against elevated nitrite concentration. Each pond was equipped with an electric paddlewheel aerator $(2 \mathrm{hp} / \mathrm{acre})$ that was operated nightly. When necessary, ponds were aerated during the day to maintain minimum DO concentrations.

Our approach in both studies was to consider the stocker Channel Catfish as the carryover fish, such that at the start of each experiment carryover fish size and biomass approximated conditions expected at the beginning of the growing season based on a stocking rate of the previous season of 6,000 fingerlings/acre and a 75\% survival rate. Stockers for both studies were size-graded using the UAPB grader (Trimpey et al. 2004) to obtain a uniformly sized population for stocking. In study 1 , each pond was stocked with fingerlings (understock; $44 \mathrm{lb} /$ $1,000 \mathrm{fish}$ ) at 6,000 fish/acre and stockers (carryover fish; 0.50 $\pm 0.10 \mathrm{lb} / \mathrm{fish}$, mean $\pm \mathrm{SD}$ ) at 4,500 fish/acre. Fingerlings were stocked into ponds on February 27, 2002, followed by stockers on March 7-12, 2002. In study 2, stockers (carryover fish; 0.53 $\pm 0.15 \mathrm{lb} /$ fish) were stocked into each pond at 3,500, 4,500, or 5,500 fish/acre; $60 \%$ of each pond's population was stocked on April 18, 2003, and remaining fish were stocked $10 \mathrm{~d}$ later. Fish in each pond in both studies were fed daily as much floating feed containing 32\% protein (ARKAT, Dumas, Arkansas) as they could consume in 20 min (apparent satiation) and the amount was recorded.

The fish population in each pond was sampled using a seine net (0.5-in square mesh) at approximately 30 -d intervals beginning 91 and $86 \mathrm{~d}$ after stocking in studies 1 and 2, respectively. At each pond, 100-200 fish each of fingerlings and carryover fish were weighed individually to the nearest $0.01 \mathrm{lb}$ and returned to the pond. When the mean individual weight for carryover fish (study 1) in all ponds reached target weights of 1.25 and $1.75 \mathrm{lb} / \mathrm{fish}$, three randomly selected ponds were harvested for each target weight on August 1 (147 d poststocking) and September 5 (182 d poststocking), respectively. The remaining three ponds (target weight, $2.25 \mathrm{lb} /$ fish) were harvested $235 \mathrm{~d}$ after stocking on October 28. Study 2 ponds were harvested October 7-10. Each pond was seined twice at harvest in both studies and then drained, and any fish on the pond bottom were 
collected by hand. Fish from each pond were counted by type (understock or carryover), weighed in bulk (to the nearest $1 \mathrm{lb}$ ), and a random sample of 100-200 fish of each type was weighed individually (to the nearest $0.01 \mathrm{lb}$ ).

Pond DO concentration and temperature were measured twice daily at about 0700 and 1600 hours and recorded. During study 1 , mean early morning weekly DO concentrations averaged $6.5,6.0$, and $6.0 \mathrm{mg} / \mathrm{L}$ in ponds used for the 1.25-, $1.75-$, and $2.25-\mathrm{lb} /$ fish target weight treatments, respectively, and did not differ significantly $(P=0.422)$. Respective mean afternoon DO concentrations did not differ significantly $(P=$ 0.082 ) among treatments and were $10.2,9.3$, and $9.7 \mathrm{mg} / \mathrm{L}$. In study 2 mean early morning pond DO concentration did not differ significant among treatments, but treatment means (5.7, 5.4 , and $5.2 \mathrm{mg} / \mathrm{L}$ in the ponds used for the 3,500-, 4,500-, and 5,500-fish/acre stocking rates, respectively) approached a linear relationship with stocking rate $(P=0.056)$. No significant differences $(P=0.223)$ were detected among treatments for afternoon DO, which averaged 8.2, 9.2, and $9.5 \mathrm{mg} / \mathrm{L}$ for ponds having the low, medium, and high stocking rates, respectively.

Chloride (Hach low-range test kit), total ammonia nitrogen (TAN; Hach method 10031, salicylate method), and nitritenitrogen $\left(\mathrm{NO}_{2}-\mathrm{N}\right.$; Hach method 10019, diazotization method) concentrations in the ponds were measured approximately every 2.5 weeks during study 1 . These analyses were not performed during study 2.

Processing yield was determined on a sample of fish harvested from the $2.5-\mathrm{lb} / \mathrm{fish}$ treatment of the first-year study (Green and Engle 2004). From 7 to 10 fish were selected at random from all harvested fish for weight classes 1.0-1.5 through 4.0-4.5 $\mathrm{lb} / \mathrm{fish}$, but only three fish were encountered for the 4.5-5.0-1b/fish size-class. Fish were euthanized by cranial percussion followed by pithing and weighed individually. Fish were skinned and eviscerated and heads were removed by hand. The skin and head were weighed separately. The visceral fat was removed and weighed. The dressed carcasses (no head, skin, or viscera) were weighed. Fillets were removed, weighed, and trimmed by hand, and trimmed (shank) fillets and nuggets (belly flap) were weighed. All results were reported as percentages of whole-body weight.

Once homogeneity of variance and normality were confirmed, data were analyzed using the UNIVARIATE, FREQ, MIXED, and REG procedure in SAS (version 9.4, SAS Institute, Cary, North Carolina). Target weight (study 1), stocking rate (study 2), and weight class (first-year study) were fixed effects, and pond (studies 1 and 2) and fish (first-year study) were the random effects. Study 1 final weight and gross and net yield were not analyzed statistically because the experimental design called for harvest at different target weights for carryover fish. Growth data were analyzed by linear regression analysis (REG procedure) and regression line slopes were compared using the MIXED procedure; only growth data for study 1 had to be linearized by natural logarithm transformation for analysis. Survival data were square-root-arcsine transformed for analysis.
Study 2 treatment means were evaluated by linear and quadratic orthogonal contrasts. Individual carryover fish weights at harvest for each pond were assigned to various weight classes $(<0.5 \mathrm{lb}$ /fish, $0.5-3.0 \mathrm{lb} /$ fish in 0.25-lb increments, and 3.0-4.0 $\mathrm{lb} /$ fish) for chi-square analysis; an individual weight was included in a particular data bin if the lowest bound $\leq$ number $<$ largest bound.

\section{RESULTS}

\section{Study 1}

Channel Catfish carryover fish growth (log $e$-transformed data) was linear to all target weights in multiple-batch culture. Growth curves (back transformed) were $y=0.4862 e^{(0.0071 x)}$ $\left(R^{2}=0.983, P<0.001\right), y=0.4795 e^{(0.0074 x)}\left(R^{2}=0.980\right.$, $P<0.001)$, and $y=0.4935 e^{(0.0070 x)}\left(R^{2}=0.971, P<0.001\right)$ for growth up to the 1.25-, 1.75-, and 2.25-lb/fish target weights, respectively, where $y=$ mean individual weight $(\mathrm{lb} / \mathrm{fish})$ and $x=$ grow-out day. Understocked fish growth ( $\log e$-transformed data) also was linear and was described in back-transformed form by $y=0.0387 e^{(0.0119 x)}\left(R^{2}=0.920, P<0.001\right), y=$ $0.0346 e^{(0.0126 x)}\left(R^{2}=0.928, P<0.001\right)$, and $y=0.0376 e^{(0.0125 x)}$ $\left(R^{2}=0.965, P<0.001\right)$ in the $1.25-, 1.75-$, and $2.25-1 \mathrm{~b} / \mathrm{fish}$ target weight treatments, respectively. No significant differences among growth curve slopes were detected for carryover fish $(P=0.175)$ or understocked fish $(P=0.260)$.

Mean daily feed rations were 64,76 , and $71 \mathrm{lb} / \mathrm{acre}$ and maximum daily feed rations were 162,177 , and $166 \mathrm{lb} / \mathrm{acre}$ for the 1.25-, 1.75-, and 2.25-lb/fish target weight treatments, respectively. Survival of carryover and understocked fish and overall FCR did not differ significantly among target weights treatments (Table 1). The overall mean survival was $90.0 \%$ for carryover fish and $47.8 \%$ for understocked fish. The overall FCR averaged 1.8.

Mean weights of carryover fish at harvest approximated the target weights (Table 1). The percentages of carryover fish that exceeded 1.25 and $1.50 \mathrm{lb} /$ fish target weights and the maximum individual weight encountered during growth samples and at harvest are presented in Table 2. The cumulative mean percent of carryover fish at harvest equal to or larger than a given size-class for each target size decreased as size-class increased (Figure 1).

The mean CV (100.SD/mean) of weight for carryover and understocked fish remained relatively constant throughout the experiment (Table 1). Mean individual weight $\mathrm{CV}$ at stocking was $19.5 \%$ for carryover fish. Understocked fish were not weighed individually at stocking; at the day-91 sample, mean individual weight CV was $34.4 \%$. Skewness $\left(g_{1}\right)$, a measure of a distribution's symmetry about its mean, indicated that initial $\left(g_{1}=0.19\right)$ and final individual weight distributions for carryover fish were approximately symmetric (Table 1). Individual weight distributions of understocked fish were approximately symmetric $\left(g_{1}=0.42\right)$ at the day-91 sample and skewed to the right $\left(g_{1}=0.85\right)$ at harvest from the $1.25-\mathrm{lb} /$ fish target weight 
TABLE 1. Least-squares mean final weight, gross and net yield, and survival of stocker (carryover fish) and understocked (fingerling) Channel Catfish, and total feed and FCR. Final weight and gross and net yield were not analyzed statistically because the experimental design called for harvest at different target weights. Means within a row followed by different letters are significantly different at the indicated probability level. Initial weights (mean \pm SD) of carryover and understocked fish were $0.50 \pm 0.10$ and $0.044 \pm 0.002 \mathrm{lb} /$ fish, respectively.

\begin{tabular}{|c|c|c|c|c|c|}
\hline \multirow[b]{2}{*}{ Variable } & \multicolumn{3}{|c|}{ Target weight (lb/fish) } & \multirow[b]{2}{*}{ Pooled SE } & \multirow[b]{2}{*}{$\operatorname{Pr}>F$} \\
\hline & 1.25 & 1.75 & 2.25 & & \\
\hline \multicolumn{6}{|c|}{ Carryover fish } \\
\hline Final weight (lb/fish) & 1.4 & 1.9 & 2.2 & & \\
\hline $\mathrm{CV}(\%)$ & 18.8 & 20.1 & 24.1 & & \\
\hline Skewness $\left(g_{1}\right)$ & 0.02 & 0.03 & -0.14 & & \\
\hline Kurtosis $\left(g_{2}\right)$ & -0.17 & -0.10 & -0.11 & & \\
\hline Gross yield (lb/acre) & 5,304 & 7,464 & 8,829 & & \\
\hline Net yield (lb/acre) & 3,113 & 5,274 & 6,639 & & \\
\hline Net daily yield (lb/acre per day) & $21.3 \mathrm{y}$ & $29.1 \mathrm{z}$ & $27.4 \mathrm{zy}$ & 1.6 & 0.033 \\
\hline Survival (\%) & 89.0 & 91.3 & 89.5 & 0.7 & 0.942 \\
\hline \multicolumn{6}{|c|}{ Understocked fish } \\
\hline Final weight (lb/fish) & 0.22 & 0.37 & 0.55 & & \\
\hline $\mathrm{CV}(\%)$ & 37.3 & 33.6 & 39.4 & & \\
\hline Skewness $\left(g_{1}\right)$ & 0.85 & 0.34 & 0.08 & & \\
\hline Kurtosis $\left(g_{2}\right)$ & 1.37 & -0.35 & -1.05 & & \\
\hline Gross yield (lb/acre) & 816 & 966 & 1,285 & & \\
\hline Net yield (lb/acre) & 575 & 726 & 1,045 & & \\
\hline Net daily yield (lb/acre per day) & 3.9 & 4.0 & 4.2 & 1.0 & 0.987 \\
\hline Survival (\%) & 58.3 & 48.9 & 39.2 & 0.8 & 0.474 \\
\hline Total feed (lb/acre) & 7,081 & 10,743 & 13,390 & & \\
\hline Overall FCR & 2.0 & 1.8 & 1.8 & 0.1 & 0.493 \\
\hline
\end{tabular}

TABLE 2. Mean percent of the carryover (stocker) Channel Catfish population that exceeded 1.25 and $1.50 \mathrm{lb} /$ fish, and maximum individual weight during the growing season in a multiple-batch (study 1) or single-batch (study 2) culture.

\begin{tabular}{llccc}
\hline & & \multicolumn{2}{c}{ Percent of population } & \\
\cline { 2 - 3 } Study and stocking rate & Date & $\geq 1.25 \mathrm{lb} /$ fish & $\geq 1.50 \mathrm{lb} /$ fish & Maximum (lb/fish) \\
\hline Study 1: 4,500/acre & Jun 6 & 3.2 & 0.4 & 0.88 \\
& Jul 1 & 21.6 & 2.8 & 1.74 \\
& Aug 1 & 70.4 & 34.0 & 2.04 \\
& Sep 5 & 94.7 & 83.2 & 2.97 \\
& Oct 28 & 93.8 & 87.7 & 3.68 \\
Study 2: 3,500/acre & Jul 14 & 66.3 & 41.3 & 2.75 \\
& Aug 14 & 85.3 & 65.3 & 3.01 \\
& Sep 12 & 94.7 & 84.8 & 3.45 \\
Study 2: 4,500/acre & Oct 8 & 95.7 & 90.0 & 3.93 \\
& Jul 14 & 54.0 & 24.0 & 2.75 \\
& Aug 14 & 76.3 & 49.0 & 3.01 \\
Study 2: 5,500/acre & Sep 12 & 83.5 & 62.0 & 3.45 \\
& Oct 8 & 90.1 & 78.9 & 3.93 \\
& Jul 14 & 35.7 & 13.0 & 1.85 \\
& Aug 14 & 64.3 & 39.0 & 2.55 \\
& Sep 12 & 77.9 & 58.5 & 3.05 \\
& Oct 8 & 87.0 & 73.0 & 3.34 \\
\hline
\end{tabular}




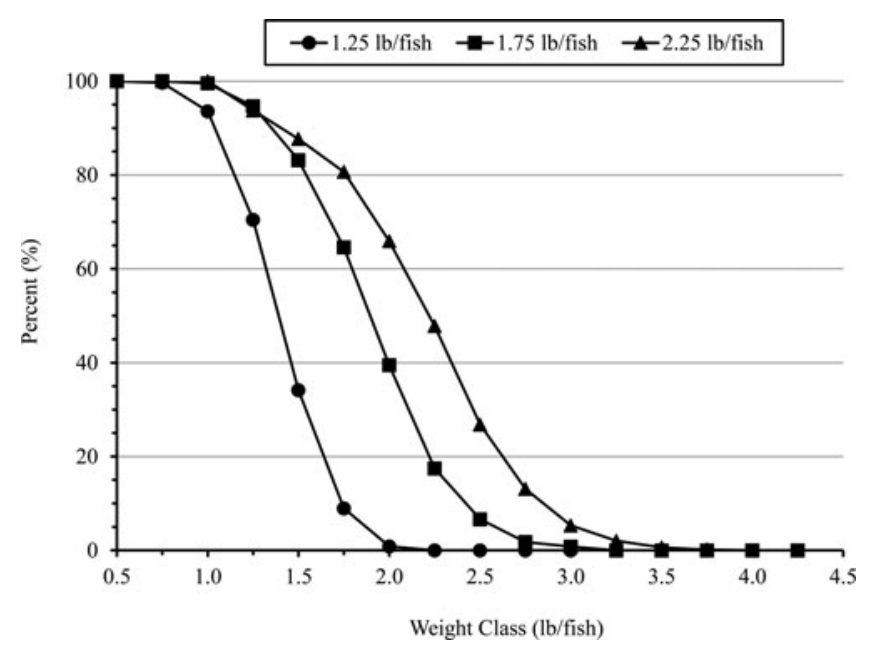

FIGURE 1. The mean percentage of the carryover Channel Catfish population at harvest of 1.25-, 1.75-, and 2.25-lb/fish target weight ponds that exceed each weight class.

ponds. Otherwise, distributions were approximately symmetric. Kurtosis $\left(g_{2}\right)$, a measure of the central peak's height and sharpness relative to the rest of the data, indicated that the individual weight distributions were approximately normal (mesokurtic) for the carryover and understocked fish at stocking and at day 91, respectively (Table 1). Carryover fish size distributions at harvest were slightly flatter (platykurtic) than a normal distribution. Size distribution of understocked fish was more peaked (leptokurtic) at harvest from the 1.25-lb/fish target weight ponds, but became increasingly flatter at each subsequent harvest.

Carryover fish size-class distributions differed significantly among target weights $(P<0.001)$. Size-class distribution progressively shifted towards larger size-classes as target weight increased. There were greater than expected numbers of 0.75 $1.25-\mathrm{lb}$ fish in the $1.25 \mathrm{-lb} /$ fish target weight group, whereas for the other two target weights there were fewer than expected fish. There were greater than expected numbers of 1.75-2.00-lb fish in the $1.75-\mathrm{lb} /$ fish target weight population than in the other treatments. And, the $2.25-\mathrm{lb} / \mathrm{fish}$ target weight population had greater than expected numbers of 2.25-4.00-lb fish than in the other two treatments.

Mean chloride concentration did not differ significantly $(P=$ 0.954 ) among treatments and was 93,100 , and $113 \mathrm{mg} / \mathrm{L}$ for the $1.25-, 1.75-$, and $2.25-\mathrm{lb} /$ fish target weight treatments, respectively. No significant difference $(P=0.221)$ was detected among treatments for TAN, which averaged $0.47,0.69$, and $0.80 \mathrm{mg} / \mathrm{L}$ in the 1.25-, 1.75-, and 2.25-lb/fish target weight treatments, respectively. The respective $\mathrm{NO}_{2}-\mathrm{N}$ means were $0.04,0.04$, and $0.06 \mathrm{mg} / \mathrm{L}$ and did not differ significantly among treatments $(P=0.526)$.

\section{Study 2}

Stocking rate affected Channel Catfish growth and yield significantly (Table 3 ). Mean final weight decreased linearly and gross and net yields increased linearly with increased stocking rate. Mean daily feed ration increased linearly $(P=0.004)$ with stocking rate and was 59, 64, and $70 \mathrm{lb} / \mathrm{acre}$ for the 3,500-, 4,500-, and 5,500-fish/acre stocking rates, respectively; maximum daily feed ration was 139,169 , and $185 \mathrm{lb} / \mathrm{acre}$, respectively. Feed conversion ratio did not differ significantly among stocking rates and averaged 1.9 overall.

Stocker growth curves were linear: $y=0.5567+0.0102 x$ $\left(R^{2}=0.966, P<0.001\right), y=0.5492+0.0080 x\left(R^{2}=0.974\right.$, $P<0.001)$, and $y=0.4960+0.0079 x\left(R^{2}=0.982, P<\right.$ 0.001 ) for the 3,500-, 4,500-, and 5,500-fish/acre stocking rates, respectively, where $y=$ mean individual weight (lb/fish) and $x=$ grow-out day. Catfish stocked at 3,500 fish/acre grew faster than at $4,500 \mathrm{fish} /$ acre $(P=0.018)$ or $5,500 \mathrm{fish} /$ acre $(P=$ 0.016). There was no significant difference $(P=0.992)$ in growth rates between the 4,500- and 5,500-fish/acre stocking rates.

TABLE 3. Least-squares mean final weight, gross and net yield, and survival of stocker Channel Catfish stocked at 3,500, 4,500, and 5,500 fish/acre, and total feed and FCR. Probability levels for linear and quadratic orthogonal contrasts are shown. Initial stocker weight was $0.53 \pm 0.15 \mathrm{lb} / \mathrm{fish}$.

\begin{tabular}{|c|c|c|c|c|c|c|}
\hline \multirow[b]{2}{*}{ Variable } & \multicolumn{3}{|c|}{ Stocking rate (fish/acre) } & \multirow[b]{2}{*}{ Pooled SE } & \multicolumn{2}{|c|}{$\operatorname{Pr}>F$} \\
\hline & 3,500 & 4,500 & 5,500 & & Linear & Quadratic \\
\hline Final weight (lb/fish) & 2.2 & 1.9 & 1.8 & 0.1 & 0.003 & 0.123 \\
\hline $\mathrm{CV}(\%)$ & 27.2 & 26.9 & 29.0 & & & \\
\hline Skewness $\left(g_{1}\right)$ & 0.18 & 0.38 & 0.40 & & & \\
\hline Kurtosis $\left(g_{2}\right)$ & -0.20 & -0.06 & -0.28 & & & \\
\hline Gross yield (lb/acre) & 6,522 & 7,254 & 8,497 & 259 & 0.002 & 0.451 \\
\hline Net yield (lb/acre) & 4,591 & 4,802 & 5,533 & 256 & 0.041 & 0.439 \\
\hline Net daily yield (lb/acre per day) & 28.2 & 29.5 & 33.9 & 1.6 & 0.041 & 0.439 \\
\hline Survival (\%) & 86.9 & 87.5 & 89.6 & 0.4 & 0.645 & 0.876 \\
\hline Total feed (lb/acre) & 8,924 & 9,663 & 10,455 & 280 & 0.008 & 0.940 \\
\hline FCR & 1.9 & 2.0 & 1.9 & 0.1 & 0.616 & 0.277 \\
\hline
\end{tabular}




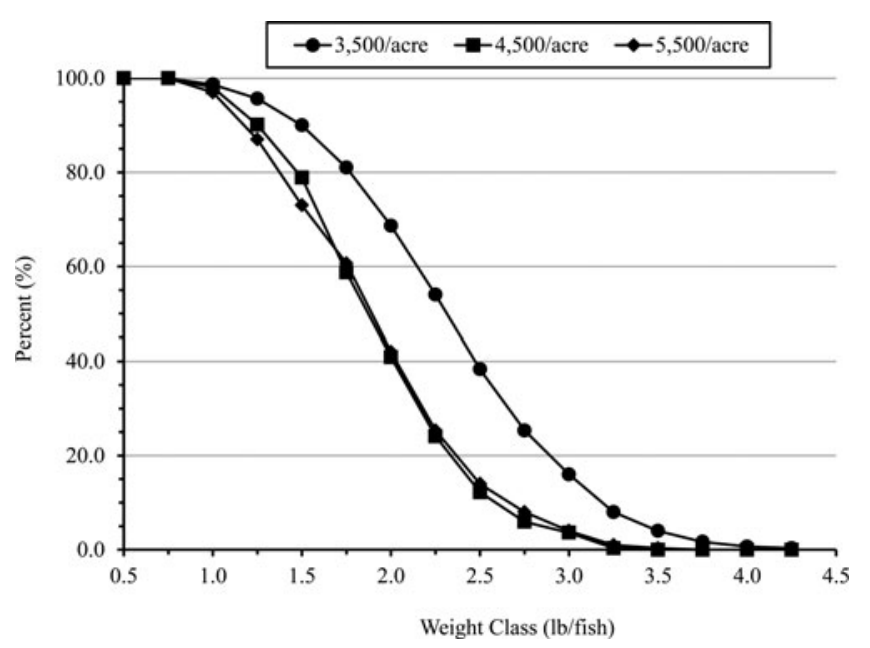

FIGURE 2. The mean percentage of the carryover Channel Catfish population at harvest for stocking rates of 3,500, 4,500, and 5,500 fish/acre that exceed each weight class.

Mean individual weight $\mathrm{CV}$ at stocking was $23.4 \%$ and at harvest was consistent among stocking rates (Table 2). No significant differences $(P>0.05)$ were detected for $\mathrm{CV}$ among treatments at stocking or harvest or within treatments between stocking and harvest. The mean individual weight distribution at stocking was skewed to the right $\left(g_{1}=0.76\right)$ and more peaked than a normal distribution $\left(g_{2}=1.20\right)$. Mean individual weight distributions at harvest were approximately symmetric and slightly flatter than a normal distribution (Table 2).

The percentages of carryover fish that exceeded target weights of 1.25 and $1.50 \mathrm{lb} /$ fish and the maximum individual weight encountered during growth samples and at harvest are presented in Table 2. The cumulative mean percent of fish equal to or larger than a given size-class at harvest was higher at the 3,500-fish/acre stocking rate than at the other two stocking rates, the results of which were similar (Figure 2).

Size-class distributions differed significantly among stocking rates $(P<0.001)$. The 3,500-fish/acre size-class distribution was shifted towards larger fish compared with the other two stocking rates. There were greater than expected numbers of $1.50-\mathrm{lb}$ and 1.00-1.25-lb fish at the 4,500- and 5,500-fish/acre stocking rates, respectively, whereas for the 3,500-fish/acre stocking rate there were fewer than expected 1.00-1.50-lb fish. There were greater than expected numbers of $2.50-4.00-1 b$ fish in ponds stocked at 3,500 fish/acre compared with the higher stocking rates, which had fewer than expected numbers of 2.75-4.00-lb fish.

\section{Dress-Out Results (First-Year Study)}

From the initial first-year study, significant differences among weight classes were detected only for nugget (belly flap) yield and visceral fat (Table 4). Nuggets from fish smaller than $2.5 \mathrm{lb} /$ fish were significantly smaller as a percentage of total weight than those from from larger fish. Visceral fat from fish in the 1.0-1.5-lb/fish weight class was significantly lower as a percentage of total weight than that for all other weight classes.

\section{DISCUSSION}

Gross and net fish yields in the current experiments were comparable with results from our earlier study (Green and Engle 2004) where 0.5-lb stockers at the same stocking rate and using the same management protocols were grown in single-batch culture to different target weights. The varied experimental designs of other studies on low-intensity Channel Catfish culture allow only general comparisons to the present studies. In ponds with carryover fish biomasses similar to that of study 1, but composed of larger stockers $(0.8-1.0 \mathrm{lb})$ and understocked with $3,000-14,000$ fingerlings/acre, total gross and net fish yields were $61-118 \%$ and $50-114 \%$, respectively, of those from study 1 (Southworth et al. 2006a, 2009). Lower initial biomasses of even larger carryover stockers understocked with varying sizes of fingerlings at 6,000 fish/acre resulted in total gross and net fish yields that were 47-68\% and 46-67\%, respectively, of study 1 yields (Engle and Valderrama 2001; Pugliese et al. 2012). In ponds stocked at 1,000-3,000 fish/acre with large stockers (800 $\mathrm{lb} / 1,000 \mathrm{fish}$ ) in single-batch culture, gross and net fish yields were $35-136 \%$ and $40-141 \%$, respectively, of study 2 yields (Engle and Kumar 2011).

Carryover fish survival in the present studies were consistent with results from other studies on low-intensity Channel Catfish culture (Engle and Valderrama 2001; Green and Engle 2004; Southworth et al. 2006a, 2009; Pugliese et al. 2012). The $39-58 \%$ survival rate of understocked fish in study 2 , while low, was comparable with the $24-58 \%$ survival reported for similar-sized (40-42 lb/1,000) fingerlings understocked in lowintensity culture ponds (Southworth et al. 2006a; Pugliese et al. 2012). Smaller understocked fingerlings experienced similarly low survival rates (Engle and Valderrama 2001; Engle et al. 2009), whereas survival increased to $68-88 \%$ when larger fingerlings were understocked (Engle and Valderrama 2001; Green et al. 2009; Southworth et al. 2009).

Exact causes of fingerling mortality in production ponds often are unknown. Cannibalism of small $(55 \mathrm{lb} / 1,000)$ by large $(0.8 \mathrm{lb} / \mathrm{fish})$ Channel Catfish was observed in an aquaria study when small fish were stocked $14 \mathrm{~d}$ after large fish, but not when small and large fish were stocked simultaneously (Unprasert et al. 1999). Testing these same experimental treatments in earthen ponds resulted in significantly lower survival when small fish were stocked $14 \mathrm{~d}$ after large fish compared with simultaneous stocking (92.9\% versus $96.9 \%$ survival, respectively), but not as low as observed in the aquaria study (75.3\% versus $98.7 \%$, respectively). Cannibalism was suspected in the pond study, but stomach content analysis of $10 \%$ of the population of large fish found no fish carcasses (Unprasert et al. 1999). Since fingerlings in study 1 were stocked $8 \mathrm{~d}$ before carryover fish, the role of cannibalism in fingerling mortality is unknown. Biting of smaller catfish by larger Channel Catfish followed 
TABLE 4. Least-squares mean \pm SE dress-out percentages by assigned weight class for Channel Catfish harvested from the 2.5-lb/fish target weight treatment ponds. Weight classes are in 0.5-lb increments. As assigned categories, whole-body data were not compared statistically. Means within a row followed by different letters are significantly different at the probability level indicated.

\begin{tabular}{|c|c|c|c|c|c|c|c|c|c|}
\hline \multirow[b]{2}{*}{ Variable } & \multicolumn{8}{|c|}{ Weight class (lb/fish) } & \multirow[b]{2}{*}{$\operatorname{Pr}>F$} \\
\hline & 1.0 & 1.5 & 2.0 & 2.5 & 3.0 & 3.5 & 4.0 & 4.5 & \\
\hline Whole body (lb) & $1.3 \pm 0.1$ & $1.7 \pm 0.1$ & $2.2 \pm 0.1$ & $2.8 \pm 0.1$ & $3.3 \pm 0.1$ & $3.6 \pm 0.1$ & $4.3 \pm 0.1$ & $4.6 \pm 0.1$ & \\
\hline Head (\%) & $22.4 \pm 0.7$ & $20.4 \pm 0.7$ & $21.5 \pm 0.7$ & $21.6 \pm 0.7$ & $21.3 \pm 0.7$ & $22.0 \pm 0.7$ & $22.3 \pm 0.8$ & $22.3 \pm 1.2$ & 0.543 \\
\hline Skin $(\%)$ & $5.3 \pm 0.2$ & $5.4 \pm 0.2$ & $4.9 \pm 0.2$ & $5.0 \pm 0.2$ & $4.5 \pm 0.2$ & $5.0 \pm 0.2$ & $5.2 \pm 0.3$ & $5.4 \pm 0.4$ & 0.139 \\
\hline Visceral fat $(\%)$ & $0.8 \pm 0.0 \mathrm{y}$ & $2.2 \pm 0.0 \mathrm{z}$ & $3.0 \pm 0.0 \mathrm{z}$ & $2.9 \pm 0.0 \mathrm{z}$ & $3.1 \pm 0.0 \mathrm{z}$ & $2.9 \pm 0.0 \mathrm{z}$ & $2.6 \pm 0.0 \mathrm{z}$ & $3.6 \pm 0.0 \mathrm{z}$ & 0.006 \\
\hline Dressed carcass $(\%)$ & $60.1 \pm 0.7$ & $60.4 \pm 0.7$ & $62.1 \pm 0.8$ & $60.1 \pm 0.7$ & $62.1 \pm 0.7$ & $62.1 \pm 0.7$ & $62.0 \pm 0.8$ & $61.0 \pm 1.2$ & 0.100 \\
\hline Fillet (\%) & $46.3 \pm 1.0$ & $46.6 \pm 1.0$ & $47.8 \pm 1.1$ & $47.1 \pm 1.0$ & $49.7 \pm 1.1$ & $48.5 \pm 1.0$ & $49.2 \pm 1.2$ & $50.4 \pm 1.8$ & 0.168 \\
\hline Shank fillet (\%) & $37.7 \pm 1.0$ & $37.2 \pm 1.0$ & $38.7 \pm 1.1$ & $37.4 \pm 1.0$ & $40.1 \pm 1.0$ & $38.3 \pm 1.0$ & $37.7 \pm 1.2$ & $39.7 \pm 1.8$ & 0.493 \\
\hline Nugget $(\%)$ & $8.6 \pm 0.3 \mathrm{y}$ & $9.4 \pm 0.3 \mathrm{y}$ & $9.1 \pm 0.3 \mathrm{y}$ & $9.8 \pm 0.3 \mathrm{zy}$ & $10.1 \pm 0.3 \mathrm{z}$ & $10.2 \pm 0.3 \mathrm{z}$ & $10.7 \pm 0.3 \mathrm{z}$ & $10.8 \pm 0.5 \mathrm{z}$ & $<0.001$ \\
\hline $\begin{array}{c}\text { Head : whole } \\
\text { body }(\%)\end{array}$ & $22.4 \pm 0.5$ & $20.4 \pm 0.5$ & $20.5 \pm 0.6$ & $21.6 \pm 0.5$ & $22.0 \pm 0.6$ & $22.0 \pm 0.5$ & $22.3 \pm 0.6$ & $22.3 \pm 1.0$ & 0.080 \\
\hline $\begin{array}{c}\text { Fillet : dressed } \\
\text { carcass }(\%)\end{array}$ & $76.8 \pm 1.3$ & $77.2 \pm 1.3$ & $77.3 \pm 1.5$ & $78.6 \pm 1.3$ & $79.9 \pm 1.4$ & $78.0 \pm 1.3$ & $79.3 \pm 1.5$ & $82.6 \pm 2.4$ & 0.379 \\
\hline $\begin{array}{l}\text { Shank fillet : } \\
\text { dressed } \\
\text { carcass }(\%)\end{array}$ & $62.6 \pm 1.3$ & $61.5 \pm 1.3$ & $62.7 \pm 1.6$ & $62.3 \pm 1.3$ & $64.5 \pm 1.4$ & $61.7 \pm 1.3$ & $60.8 \pm 1.6$ & $65.0 \pm 2.4$ & 0.648 \\
\hline
\end{tabular}


by opportunistic bacterial infection of the resulting wound can cause mortality, but small $(110 \mathrm{lb} / 1,000)$ fish rarely sustained bites by large fish (0.9-2.1 lb/fish), especially when fish were fed (Lochmann et al. 1998). Causes of catfish fingerling mortality in earthen ponds include poststocking stress-induced disease and predation (e.g., by birds, snakes, turtles), both of which likely contributed to the study 1 results.

Growth of individual fish within a population is affected by social interactions, mediated most commonly by competition for food among individuals (Brett 1979; Jobling 1983; Jobling and Wandsvik 1983; Huss et al. 2008). Size variation within the population, as measured by the $\mathrm{CV}$, would be expected to increase with increased competition if food is assumed to be distributed according to a size hierarchy. Competition between understocked fingerlings and carryover fish or in response to an increased stocking rate are factors that affect population size distribution. Coefficients of variation of individual Channel Catfish weight at harvest converge towards 30-40\% (Konikoff and Lewis 1974) and are unaffected by stocking rates that range from 8.4 to 20.8 fish/ $\mathrm{ft}^{2}$ in cages (Konikoff and Lewis 1974; Kilambi et al. 1977) or from 0.5 to $4.1 \mathrm{fish} / \mathrm{ft}^{2}$ in the biofloc production system (Schrader et al. 2011; Green and Schrader 2015). Individual weight CVs above or below the $30-40 \%$ range in the initial population will tend to move towards that range during the culture period. Individual weight CVs at harvest in studies 1 and 2 appeared to follow this general trend. It is unlikely, however, that competition for food was appreciable during the present studies because fish were fed daily to apparent satiation and individual weight $\mathrm{CV}$ s at harvest were similar among treatments.

Size-grading the initial Channel Catfish population significantly reduces individual size variation at harvest and yields a significantly greater proportion of market-sized fish compared with that an ungraded population (Greenland et al. 1983). The reduction in size variability gained by initial population sizegrading appeared to be conserved throughout studies 1 and 2 . In a previous study where size-graded stocker Channel Catfish were grown in single-batch culture to $1.25-2.50 \mathrm{lb} / \mathrm{fish}$, initial weight $\mathrm{CV}(23.1 \%)$ increased to CVs that ranged from $24.8 \%$ to $29.2 \%$ at harvest (Green and Engle 2004). Although a direct comparison is not valid, it appears that the understocked fingerlings did not affect carryover fish size variation at harvest given the similarity in the CVs from study 1 and Green and Engle (2004). Understock fingerling size (Engle and Valderrama 2001) or stocking rate (Southworth et al. 2009), however, can reduce carryover Channel Catfish growth. The significantly slower growth of carryover fish in ponds understocked with $82 \mathrm{lb} / 1,000$ fingerlings compared with ponds understocked with $26 \mathrm{lb} / 1,000$ or smaller fingerlings (Engle and Valderrama 2001) or in ponds understocked with $198 \mathrm{lb} / 1,000$ fish at 4,5006,000 fish/acre compared with 3,000 fish/acre (Southworth et al. 2009) was attributed to competition for feed despite fish being fed to apparent satiation. However, in a 3-year Channel Catfish production study, mean individual weight of harvested fish did not differ significantly for fish grown in single- or multiple-batch culture (Tucker et al. 1993). Stomach content analysis of small fingerlings in multiple-batch culture ponds showed that natural food items predominated (Tucker et al. 1993).

Channel Catfish growth is affected by stocking rate during all production phases independent of the production system (e.g., Allen 1974; Dunham et al. 1990; Li et al. 2003; Baumgarner et al. 2005; Green and Schrader 2015). Although individual growth rate and fish size at harvest vary inversely with stocking rate, yield increases with stocking rate when feed is not limiting because of the greater number of fish. Despite being fed to apparent satiation, a diet formulated to meet nutritional needs, and no statistically significant differences among FCR, feed intake per fish and individual weight decreased linearly as stocking rate increased in study 2 . The $16-28 \%$ reduction in feed intake per fish we observed as stocking rate increased from 3,500-5,500 fish/acre is comparable with the $21-32 \%$ decrease in feed intake per Channel Catfish as stocking rate increased from 6,000-18,000 fish/acre (Robinson and Li 2008). Similarly, feed intake decreased by $25-39 \%$ as Channel Catfish stocking rate increased from 1,000-3,000 fish/acre (Engle and Kumar 2011). Feed consumption and growth of Channel Catfish are inversely related to pond DO concentrations below $40 \%$ saturation, approximately equivalent to $3.5 \mathrm{mg} / \mathrm{L}$ at summer pond water temperatures (Torrans 2008; Green and Rawles 2011), but in study 2 mean early morning DO concentrations exceeded this threshold. Thus, early morning DO concentrations do not appear to explain the decreased feed intake in catfish among the treatments. Ammonia and nitrite, which were not measured in study 2, can be growth-limiting or toxic to Channel Catfish (Colt and Tchobanoglous 1976; Colt et al. 1981; Hargreaves and Kucuk 2001). However, since ponds in studies 1 and 2 were managed similarly and measured TAN and $\mathrm{NO}_{2}-$ $\mathrm{N}$ concentrations were low during study 1 , it is unlikely that water quality restricted feed intake by catfish during study 2 . Robinson and $\mathrm{Li}$ (2008) also were unable to attribute decreased feed intake and growth to water quality, but rather hypothesized based upon the apparent inverse stocking rate-survival relationship that density-dependent stressors related to crowding were responsible.

Although decreased feed intake in response to increased stocking rate has been attributed to density-dependent mortality, similar survival of catfish among stocking rates in study 2 precludes differential mortality as an explanation for the decreased feed intake. Stress, as measured by serum cortisol level, in Channel Catfish stocked at 0.5-2.0 fish/gal in flow-through aquaria was low and did not differ significantly with stocking rate (Gatlin et al. 1986). Klinger et al. (1983) reported for catfish stocked at 1.2-14.2 $\mathrm{fish} / \mathrm{ft}^{2}$ in flow-through tanks that serum cortisol concentrations were low and unaffected by density, whereas Ainsworth et al. (1985) found that serum cortisol concentration in fish stocked in ponds at 4,000 fish/acre was significantly lower than in fish stocked at 6,000 or $8,000 \mathrm{fish} / \mathrm{acre}$. Serum cortisol concentrations were less than $10 \mu \mathrm{g} / \mathrm{dL}$ in all these 
studies (Klinger et al. 1983; Ainsworth et al. 1985; Gatlin et al. 1986). Thus, based on these published studies density-induced stress as indicated by serum cortisol concentration does not appear to explain the observed decrease in individual fish feed consumption. The cause of decreased feed intake by individual fish in response to increased stocking rate remains unknown, but likely is related to some aspect of social interaction and requires further investigation.

Feed conversion ratios in the present experiments were comparable with FCRs reported for other low-intensity Channel Catfish studies (Engle and Valderrama 2001; Green and Engle 2004; Southworth et al. 2006a, 2006b). Reported effects of stocking rate on FCR in low-intensity Channel Catfish culture are varied and reflect differences in experimental design. No significant differences in FCR were detected over a range of stocking rates in single- (Southworth et al. 2006b) or multiple-batch (Engle and Valderrama 2001; Southworth et al. 2006a) culture. Over a 3 -year study period, mean FCR was significantly higher for the higher stocking rate (Tucker et al. 1993), but Engle and Kumar (2011) found a significantly higher FCR for Channel Catfish stocked at 1,000 fish/acre than at 2,000 and 3,000 fish/acre. No differences in FCR are expected between the present and cited studies because feed wastage is minimized when fish are fed daily to apparent satiation.

Growing larger Channel Catfish did not affect dress-out percentages except for visceral fat and nugget percentages. The significantly lower visceral fat in fish from the smallest weight class likely resulted from restricted access to feed caused by size-related social interactions within the fish population. Relative growth and metabolic rate are higher in smaller fish than in larger fish, which results in less fat deposition by smaller fish (Salam and Davies 1994) and may have contributed to the lower visceral fat present in fish from the smallest weight class. The cause of the significantly lower nugget percentage observed for fish from the three smallest weight classes is unknown, but may be related to the lower fat content of smaller fish (Salam and Davies 1994). Dress-out and visceral fat percentages for the current study were consistent with values reported for Channel Catfish that averaged 0.9-2.0 lb/fish (Robinson and Li 1998, 1999a, 1999b; Li et al. 2000; Bosworth et al. 2004; Bosworth and Wolters 2005). Some of the variation among reported values may depend upon whether fish were processed by hand or by using commercial processing equipment. Our results and those of Robinson and Li (1998, 1999a, 1999b) were from fish dressed by hand, while commercial equipment was used in the other cited studies.

While stocker Channel Catfish increasingly are stocked into production ponds to grow larger, market-size fish and singlebatch production from stocker to market size is economically viable (D'Abramo et al. 2013), farmers should avoid producing fish that exceed processing plant specifications, i.e., outof-size fish, which are discounted (Wiese et al. 2006). Given that fish size specifications for Channel Catfish delivered for processing vary temporally and among plants in response to market demands, $1.5-2.5 \mathrm{lb} /$ fish always should be acceptable. Partial harvest of market-size fish often occurs twice during the growing season in multiple-batch ponds and once in singlebatch ponds (Tucker et al. 1993; Engle and Valderrama 2001; Southworth et al. 2006a, 2009; Pugliese et al. 2012; D’Abramo et al. 2013). Generally, market-size fish are harvested selectively beginning in May and continuing through September. Final harvest of fish from single-batch ponds typically occurs from October through February. Channel Catfish captured at each harvest are size-graded passively using a grading net of specified mesh size to retain fish that exceed a specific minimum size range (Tucker and Robinson 1990). By early to mid-July, ponds in studies 1 and 2, stocked in the spring with 0.5-lb stockers (carryover fish), contained biomasses of market-size fish suitable for partial harvest for processing, and at least $22 \%$ of the carryover fish exceeded the processing plant's lower size limit. If fish larger than $1.5 \mathrm{lb}$ are desired, the data indicate partial harvest should be delayed until August. While none of the fish harvested from studies 1 and 2 exceeded the processors' preferred size range $(1.25-4.00 \mathrm{lb} / \mathrm{fish})$, the likelihood of occurrence of out-of-size fish appears greater in multiple-batch culture because of large fish that evade capture during partial harvests, whereas in single-batch culture few fish evade capture because ponds are seined at least twice at final harvest (Tucker et al. 1993).

In summary, results of the present studies (years 2 and 3) and those from the first year (Green and Engle 2004) indicate that larger Channel Catfish can be produced successfully using low-intensity, single- or multiple-batch culture without negative effects on FCR or dress-out percentages. However, these results should be verified in a multiyear study in larger ponds and subjected to economic analysis similar to the study conducted by Tucker et al. (1993).

\section{ACKNOWLEDGMENTS}

This research was part of USDA Agricultural Research Service (ARS) Project 6228-63660-001-00D. We thank Jeff Baxter for his assistance during study 1, the Arkansas Catfish Promotion Board for providing partial funding, the ARS and UAPB technicians and field crew, and UAPB Aquaculture/Fisheries (AQFI) Center students for their assistance. Mention of trade names or commercial products is solely for the purpose of providing specific information and does not imply recommendation or endorsement by the USDA. The USDA is an equal opportunity provider and employer.

\section{REFERENCES}

Ainsworth, A. J., P. R. Bowser, and M. H. Beleau. 1985. Serum cortisol levels in Channel Catfish from production ponds. Progressive Fish-Culturist 47:176181.

Allen, K. O. 1974. Effects of stocking density and water exchange rate on growth and survival of Channel Catfish Ictalurus punctatus (Rafinesque) in circular tanks. Aquaculture 4:29-39. 
Bastola, U., and C. R. Engle. 2012. Economically important production relationships in Channel Catfish (Ictalurus punctatus) foodfish production. Reviews in Aquaculture 4:94-107.

Baumgarner, B. L., T. E. Schwedler, A. G. Eversole, D. E. Brune, and J. A. Collier. 2005. Production characteristics of Channel Catfish, Ictalurus punctatus, stocked at two densities in the partitioned aquaculture system. Journal of Applied Aquaculture 17:75-83.

Bosworth, B. G., and W. Wolters. 2005. Effects of short-term feed restriction on production, processing and body shape traits in market-weight Channel Catfish, Ictalurus punctatus (Rafinesque). Aquaculture Research 36:344-351.

Bosworth, B. G., W. R. Wolters, J. L. Silva, R. S. Chamul, and S. Park. 2004. Comparison of production, meat yield, and meat quality traits of NWAC103 line Channel Catfish, Norris line Channel Catfish, and female Channel Catfish $\times$ male Blue Catfish $\mathrm{F}_{1}$ hybrids. North American Journal of Aquaculture 66:177-183.

Brett, J. R. 1979. Environmental factors and growth. Pages 599-675 in W. S. Hoar, D. J. Randall, and J. R. Brett, editors. Fish physiology, volume VIII. Academic Press, New York.

Colt, J., R. Ludwig, G. Tchobanoglous, and J. J. Cech. 1981. The effects of nitrite exposure on the short-term growth and survival of Channel Catfish, Ictalurus punctatus. Aquaculture 24:111-122.

Colt, J., and G. Tchobanoglous. 1976. Chronic exposure of Channel Catfish, Ictalurus punctatus, to ammonia: effects on growth and survival. Aquaculture 15:353-372.

D’Abramo, L. R., T. R. Hanson, S. K. Kingsbury, J. A. Steeby, and C. S. Tucker. 2013. Production and associated economics of fingerling-to stocker and stocker-to-grow-out modular phases for farming Channel Catfish in commercial-size ponds. North American Journal of Aquaculture 75:133-146.

Dunham, R. A., R. E. Brummett, M. O. Ella, and R. O. Smitherman. 1990. Genotype-environment interactions for growth of Blue, Channel and hybrid catfish in ponds and cages at varying densities. Aquaculture 85:143-151.

Engle, C. R., and G. Kumar. 2011. Biological feasibility and costs of production of large Channel Catfish, Ictalurus punctatus, for a specialty niche market. Journal of the World Aquaculture Society 42:667-675.

Engle, C. R., K. Ruebush, C. Leyva, and J. Trimpey. 2009. The effect of dietary protein level on Channel Catfish production characteristics when feeding alternate days in multiple-batch production. North American Journal of Aquaculture 71:138-146.

Engle, C. R., and D. Valderrama. 2001. An economic analysis of the performance of three sizes of catfish Ictalurus punctatus fingerlings understocked in multiple-batch production. Journal of the World Aquaculture Society 32:393401.

Gatlin, D. M. III, W. E. Poe, R. P. Wilson, A. J. Ainsworth, and P. R. Bowser. 1986. Effects of stocking density and vitamin C status on vitamin E-adequate and vitamin E-deficient fingerling Channel Catfish. Aquaculture 56:187-195.

Green, B., P. Perschbacher, and G. Ludwig. 2009. Effect of using Threadfin Shad as forage for Channel Catfish fed daily or every third day. North American Journal of Aquaculture 71:46-51.

Green, B. W., and C. R. Engle. 2004. Growth of stocker Channel Catfish to large market size in single-batch culture. Journal of the World Aquaculture Society 35:25-32.

Green, B. W., and S. D. Rawles. 2011. Comparative production of Channel Catfish and Channel $\times$ Blue hybrid catfish subjected to two minimum dissolved oxygen concentrations. North American Journal of Aquaculture 73:311-319.

Green, B. W., and K. K. Schrader. 2015. Effect of stocking large Channel Catfish in a biofloc technology production system on production and incidence of common microbial off-flavor compounds. Journal of Aquaculture Research and Development [online serial] 6:314.

Greenland, D. C., W. R. Robison, and S. H. Newton. 1983. Size variation of ungraded and graded Channel Catfish reared in cages. Arkansas Academy of Science Proceedings 37:34-35.

Hargreaves, J. A., and S. Kucuk. 2001. Effects of diel un-ionized ammonia fluctuation on juvenile hybrid Striped Bass, Channel Catfish, and Blue Tilapia. Aquaculture 195:163-181.
Huss, M., P. Byström, and L. Persson. 2008. Resource heterogeneity, diet shifts and intra-cohort competition: effects on size divergence in YOY fish. Oecologia 158:249-257.

Jobling, M. 1983. Effect of feeding frequency on food intake and growth of Arctic Charr, Salvelinus alpinus L. Journal of Fish Biology 23:177-185.

Jobling, M., and A. Wandsvik. 1983. Effect of social interactions on growth rates and conversion efficiency of Arctic Charr, Salvelinus alpinus L. Journal of Fish Biology 22:577-584.

Johnson, K., C. Engle, and B. Wagner. 2014. Comparative economics of US catfish production strategies: evidence from a cross-sectional survey. Journal of the World Aquaculture Society 45:279-289.

Kilambi, R. V., J. C. Adams, A. V. Brown, and W. A. Wickizer. 1977. Effects of stocking density and cage size on growth, feed conversion, and production of Rainbow Trout and Channel Catfish. Progressive Fish-Culturist 39:62-66.

Klinger, H., H. Delventhal, and V. Hilge. 1983. Water quality and stocking density as stressors of Channel Catfish (Ictalurus punctatus Raf.). Aquaculture 30:263-272.

Konikoff, M., and W. M. Lewis. 1974. Variation in weight of cage-reared Channel Catfish. Progressive Fish-Culturist 36:138-144.

Lee, J. S. 1981. Commercial catfish farming. Interstate Printers and Publishers, Danville, Illinois.

Li, M. H., B. G. Bosworth, and E. H. Robinson. 2000. Effect of dietary protein concentration on growth and processing yield of Channel Catfish Ictalurus punctatus. Journal of the World Aquaculture Society 31:592-598.

Li, M. H., B. B. Manning, E. H. Robinson, and B. G. Bosworth. 2003. Effect of dietary protein concentration and stocking density on production characteristics of pond-raised Channel Catfish Ictalurus punctatus. Journal of the World Aquaculture Society 34:147-155.

Lochmann, S. E., P. W. Perschbacher, G. E. Merry, and N. Fijan. 1998. Aggressive biting among Channel Catfish in pool studies. Progressive Fish-Culturist 60:119-126.

Nanninga, A. S., and C. R. Engle. 2010. Effects of feeding frequency on multiple-batch Channel Catfish, Ictalurus punctatus, production and costs when understocked with large stockers. Journal of the World Aquaculture Society 41:594-602.

Pugliese, N., D. Heikes, C. Engle, B. Bosworth, and R. Lochmann. 2012. Evaluation of the economics of multi-batch Channel Catfish Ictalurus punctatus production fed an industry standard and three alternative diets. Journal of Applied Aquaculture 24:271-282.

Robinson, E. H., and M. H. Li. 1998. Comparison of practical diets with and without animal protein at various concentrations of dietary protein on performance of Channel Catfish Ictalurus punctatus raised in earthen ponds. Journal of the World Aquaculture Society 29:273-280.

Robinson, E. H., and M. H. Li. 1999a. Evaluation of practical diets with various levels of dietary protein and animal protein for pond-raised Channel Catfish Ictalurus punctatus. Journal of the World Aquaculture Society 30:147153

Robinson, E. H., and M. H. Li. 1999b. Effect of dietary protein concentration and feeding rate on weight gain, feed efficiency, and body composition of pondraised Channel Catfish Ictulurus punctatus. Journal of the World Aquaculture Society 30:311-318.

Robinson, E. H., and M. H. Li. 2008. Effects of feeding diets with and without fish meal on production of Channel Catfish, Ictalurus punctatus, stocked at varying densities. Journal of Applied Aquaculture 20:233-242.

Salam, A., and P. M. Davies. 1994. Body composition of Northern Pike (Esox lucius L.) in relation to body size and condition factor. Fisheries Research 19:193-204.

Schrader, K. K., B. W. Green, and P. W. Perschbacher. 2011. Development of phytoplankton communities and common off-flavors in a biofloc technology system used for the culture of Channel Catfish (Ictalurus punctatus). Aquacultural Engineering 45:118-126.

Southworth, B. E., C. R. Engle, and K. Reubush. 2009. The effect of understocking density of Channel Catfish stockers in multiple-batch production. Journal of Applied Aquaculture 21:21-30. 
Southworth, B. E., C. R. Engle, and N. Stone. 2006a. Effect of multiple-batch Channel Catfish, Ictalurus punctatus, stocking density and feeding rate on water quality, production characteristics and costs. Journal of the World Aquaculture Society 37:452-463.

Southworth, B. E., N. Stone, and C. R. Engle. 2006b. Production characteristics, water quality, and costs of producing Channel Catfish Ictalurus punctatus at different stocking densities in single-batch production. Journal of the World Aquaculture Society 37:21-31.

Torrans, L. 2008. Production responses of Channel Catfish to minimum daily dissolved oxygen concentrations in earthen ponds. North American Journal of Aquaculture 70:371-381.

Trimpey, J., C. Engle, D. Heikes, K. B. Davis, and A. Goodwin. 2004. A comparison of new in-pond grading technology to live-car grading for food-sized Channel Catfish (Ictalurus punctatus). Aquacultural Engineering 31:263276 .

Tucker, C., and E. H. Robinson. 1990. Channel Catfish farming handbook. Van Nostrand Reinhold, New York.
Tucker, C., J. Steeby, J. Waldrop, and A. Garrard. 1993. Production characteristics and economic performance of four Channel Catfish, Ictalurus punctatus, pond stocking density-cropping system combinations. Journal of Applied Aquaculture 3:333-351.

Unprasert, P., J. B. Taylor, and H. R. Robinette. 1999. Role of stocking sequence on survival of fingerling Channel Catfish cultured in mixed-size populations. North American Journal of Aquaculture 61:235238.

USDA NAHMS (U.S. Department of Agriculture National Animal Health Monitoring System). 2010. Catfish 2010 part II: health and production practices for foodsize catfish in the United States, 2009. USDA, Animal and Plant Health Inspection Service, Center of Epidemiology and Animal Health, 595.0611, Fort Collins, Colorado.

Wiese, N., C. Engle, J. Trimpey, K. Quagrainie, and B. Green. 2006. Reducing catfish farm losses due to dockages assessed by processing plants. Journal of the World Aquaculture Society 37:60 73. 